\title{
Evaluating Tsunami Impact on the Gulf of Cadiz Coast (Northeast Atlantic)
}

\author{
R. Omira, ${ }^{1,3}$ M. A. Baptista, ${ }^{1,2}$ and J. M. Miranda ${ }^{1}$
}

\begin{abstract}
The Gulf of Cadiz coasts are exposed to tsunamis. Emergency planning tools are now taking into account this fact, especially because a series of historical occurrences were strikingly significant, having left strong evidence behind, in the mareographic records, the geological evidence or simply the memory of the populations. The study area is a strip along the Algarve coast, south Portugal, an area known to have been heavily impacted by the 1 November 1755 event. In this study we use two different tsunami scenarios generated by the rupture of two thrust faults identified in the area, corresponding to 8.1-8.3 magnitude earthquakes. Tsunami propagation and inundation computation is performed using a nonlinear shallow water code with bottom friction. Numerical modeling results are presented in terms of flow depth and current velocity with maximum values of $7 \mathrm{~m}$ and $8 \mathrm{~m} / \mathrm{s}$ for inundation depth and flow speed, respectively. These results constitute a valuable tool for local authorities, emergency and decision planners to define the priority zones where tsunami mitigation measures must be implemented and to develop tsunami-resilient communities.
\end{abstract}

Key words: Tsunami, Gulf of Cadiz, inundation maps, current velocity.

\section{Introduction}

Tsunamis originated from different triggering mechanisms are reported along the Atlantic coasts of Europe since prehistoric times. The Storegga submarine slide circa 8,000 years ago (BoNDEviK et al., 2003, 2005) in the Norwegian Sea is the oldest wellestablished event, whereas for the Gulf of Cadiz, Northeast Atlantic, the oldest described paleo-tsunami is dated 7000 BP (LuQue et al., 2001). The

1 Instituto Dom Luiz (IDL), University of Lisbon, Lisbon, Portugal. E-mail: omirarachid10@yahoo.fr; mavbaptista@gmail. com; jmmiranda@fc.ul.pt

2 Instituto Superior de Engenharia de Lisboa, Lisbon, Portugal.

3 University Ibn Tofail, Kenitra, Morocco. largest tsunami event eye-witnessed in the area is the one associated with the Lisbon 1755 earthquake (BAPTISTA et al., 1998a, b, 2003). It struck the Iberian and the North African coasts, severely damaging coastal communities, as described by a large number of historical documents that testify the impact of the tsunami waves. These littoral areas are now the location of vital sectors of the economy and tourism, are intensely populated, and the damage from a 1755 like event could be much greater.

Previous paleotsunami (LuQue et al., 2001, 2002) and historical (BAPTISTA and MiRAnda, 2009) studies focused on the Gulf of Cadiz region show that there is enough evidence to support the existence of events similar to the 1 November 1755 tsunami in Lisbon in the historical period. LuQue et al. (2001) identified three tsunami-generated deposits and also deduced an average interval of about 2,000 years between two consecutive events. In light of these results, the likely tsunami recurrence period for 1755-like events is considered quite large. In the twentieth century three tsunamis impacted the area caused by earthquakes of magnitudes close to 8 (BAPTISTA and MirandA, 2009): 25 November $1941(M=8)$ (BUFORn et al., 1988) and 28 February $1969\left(M_{s}=7.9\right)$ (FuKAO, 1973); these and the 26 May $1975\left(M_{s}=7.9\right)$ (KAABoubEN et al., 2008) events testify that the tsunami is a real menace in the Gulf of Cadiz, and thus the protection of the coastal areas of the region should be a priority.

To protect coastal communities against the tsunami threat, beside a reliable tsunami warning system, evacuation planning in the vulnerable areas is of crucial importance. Such plans require the availability of inundation maps that provide estimates of the expected damage-prone areas, the spatial distribution of flow depth and the current velocity within the flooded zone. The deterministic tsunami hazard approach based on particular source scenarios is the 
well-established tool to derive such inundation maps (Tinti and Armigliato, 2003).

In this study we employ the most credible tsunamigenic scenario approach together with numerical modeling to assess the tsunami hazard and impact along the Algarve coastal region in southern Portugal.

The study area corresponds to a $15-\mathrm{km}$ strip along the coast (cf. Fig. 1a, b for locations), which includes the towns of Lagos and Portimão with 30,000 and 50,000 inhabitants, respectively. The area is characterized by sandy beaches that are crowed during the high tourist season, when the population can easily double. The tide gauge data recorded during the 28 February 1969 (BAPTISTA et al., 1992; HeINRICH et al., 1994; GJEVIK et al., 1997) and the simulation results of the 1755 event (BAPTISTA et al., 1998b) show that this area is the first to be struck by tsunamis generated in the Gulf of Cadiz. Moreover this was one of the most devastated areas by the tsunami of 1 November 1755 (CASTRO, 1768). The effects of the 1755 tsunami in the area are described in detail by BAPTISTA et al. (2008), Baptista and Miranda (2009), and Pedrosa and Gonçalves (2008).

Tsunami impact is presented in terms of maximum wave heights (MWHs) and high-resolution inundation and current velocity maps. Both linear and non-linear approximations of shallow water equations were adopted to simulate the deep-ocean tsunami propagation and the near-shore inundation, respectively. Moreover, a sensitivity study related to the influence of the bottom friction on the variation of the maximum flow depths and the current velocities was carried out using three different values of Manning's coefficient.

Results show that both scenarios produce a dramatic tsunami impact along the whole study area. Major variations in the maximum flow depth, inundation limits and current velocity have been observed when the bottom friction coefficient is changed.

\section{Tsunami Scenarios}

To investigate the impact of tsunami events in the Gulf of Cadiz it is necessary to define the seismic scenarios able to generate tsunamis in the area. In this study we employ the concept of typical fault to infer the Maximum Credible Earthquake Scenarios (MCE). Typical faults are defined from all positively identified submarine structures in the Gulf of Cadiz large enough to generate tsunamigenic earthquakes, adding the following additional criteria: (1) having been identified by seismo-stratigraphic research, (2) providing clear identification of quaternary activity and (3) having been deduced from instrumental seismic data (Miranda et al., 2008; OMira et al., 2009a).

Recent studies focused on tsunami impact in selected areas in the Gulf of Cadiz, Casablanca in Morocco (OмiRa et al., 2009b) and Huelva in Spain (Lima et al., 2010), considered a set of five different typical faults. In this study we focus on two typical faults, both thrusts, that we consider the most relevant candidate sources: the Marques de Pombal fault (MPF) and Horseshoe fault (HSF) [cf. Fig. 2 and discussion in OMIRA et al. (2009a) and Lima et al. (2010)]. The fault characteristics and the computed earthquake magnitudes are specified in Table 1. The scaling relationship of ScHolz (1982) that is based on fault lengths and length/width relations was used to fix the slip magnitude. The magnitude shown in Table 1 is obtained from the dimensions and slip of the fault following the seismic moment definition of AKI (1966) and the $M_{o}-M_{w}$ relation defined by KanAmori and Anderson (1977). For tsunami modeling, the geometry of the candidate sources is simplified to a rectangle (cf. Fig. 2 for locations) for the computation of seafloor initial deformation.

\section{Modeling Inundation and Current Velocity}

Tsunami hydrodynamic modeling was done with a slightly modified version of the Liu et al. (1998) COMCOT code (OMIRA et al., 2009a, b) that uses an explicit leap-frog finite difference scheme to solve linear and non-linear shallow water equations on a dynamically coupled system of nested grids. The Coriolis effect is not considered in this study given the relatively small computation region in which the earth rotation effect is not prominent. Nested grids have resolutions of 800,200 and $50 \mathrm{~m}$, respectively, in order to assure a good description of bathymetric and topographic features in the area. The finer grid is focused along the Lagos-Portimão south Portuguese 


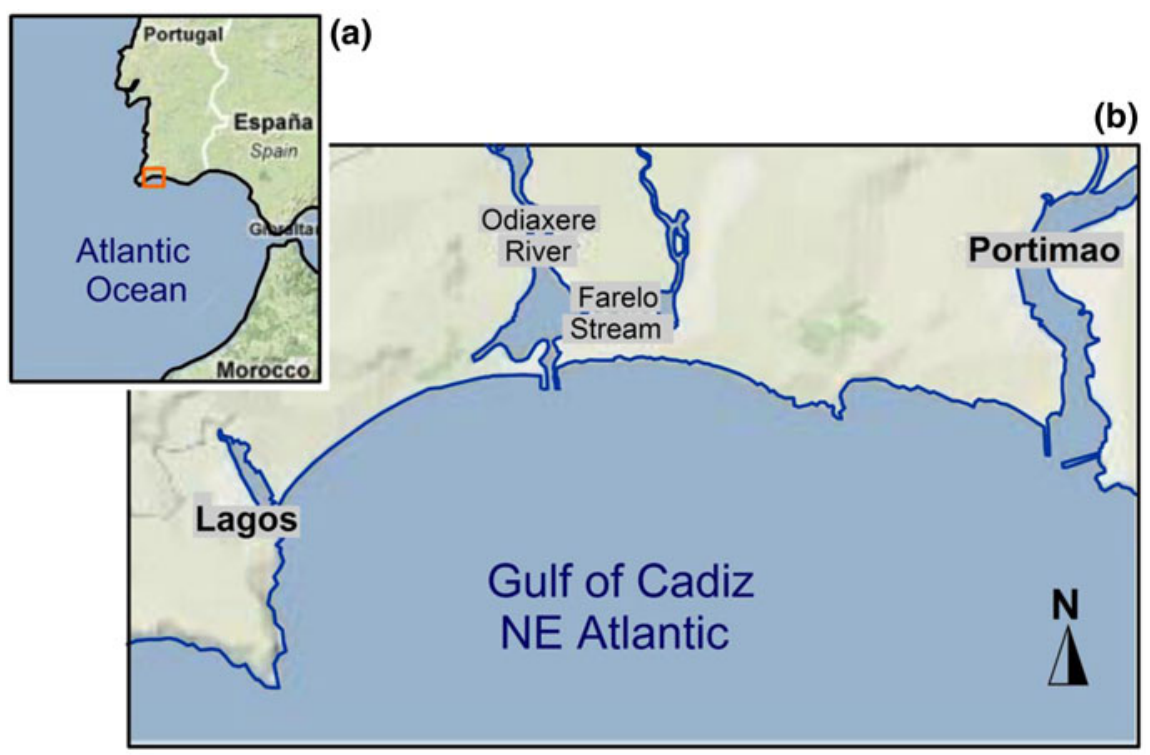

(c)

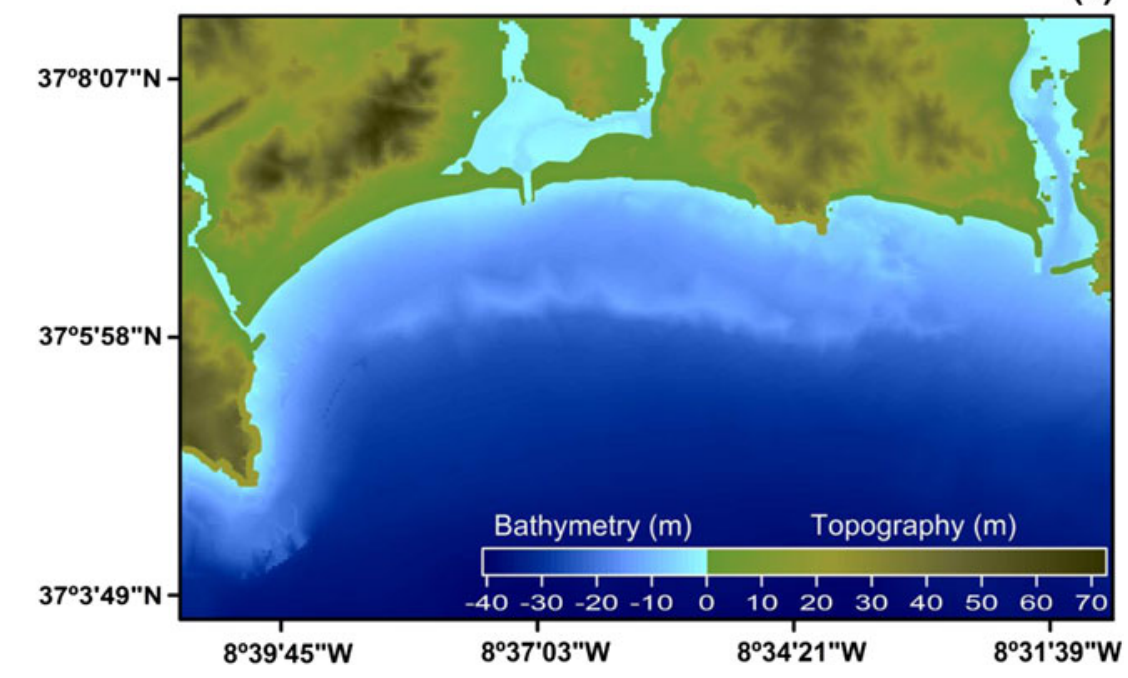

Figure 1

Location of the study area. a Regional overview of the SW Iberian margin. b Localities referred to in the text. $\mathbf{c}$ Bathymetric and topographic data used in the numerical modeling. All coordinates correspond to the UTM system, Zone 29, and are expressed in meters

coast. The digital terrain model (DTM) (bathymetry/ topography) of the Lagos-Portimão area (Fig. 1c) was generated from a compilation of multisource height/ depth data from multibeam surveys, digitized bathymetric charts and digital cartographic data. The final data set is referenced to the mean sea level, and all grids are in Cartesian coordinates (UTM 29), which are sufficiently accurate, given the size of the study area. The coupling between a sub-grid and their parent grid follows the requirements of WANG and LIU
(2007) and LiU et al. (1998). In the outer grid an open boundary radiation condition is used.

The static vertical displacement of the ocean floor due to the submarine earthquake scenario is modeled using the Mansinha and SMylie (1971) homogenous elastic half space approach, as implemented in the Mirone suite (LuIs, 2007). Slip in the source is considered non-homogeneous, following the smooth closure condition of GeIST and DMOwSKA (1999). For run-up and inundation computations, a moving 


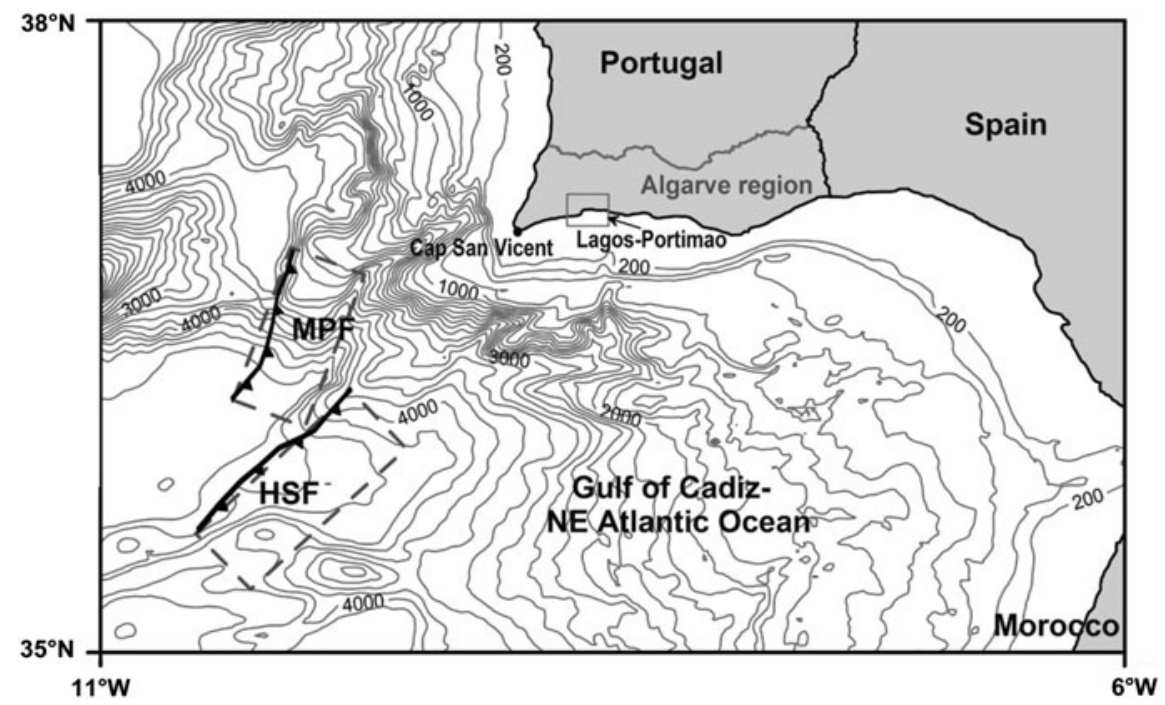

Figure 2

Typical faults used in the study. MPF Marques de Pombal fault; HSF Horsehoe fault. As a background the bathymetric data are plotted every $200 \mathrm{~m}$

Table 1

Fault parameters of the simulated tsunamigenic scenarios in the Gulf of Cadiz region

\begin{tabular}{|c|c|c|c|c|c|c|c|c|c|c|c|}
\hline \multirow[t]{2}{*}{ Scenarios name } & \multirow[t]{2}{*}{$L(\mathrm{~km})$} & \multirow[t]{2}{*}{$W(\mathrm{~km})$} & \multicolumn{2}{|c|}{ Epicenter coordinates } & \multirow[t]{2}{*}{$D(\mathrm{~km})$} & \multirow[t]{2}{*}{ Slip (m) } & \multirow[t]{2}{*}{ Strike $\left({ }^{\circ}\right)$} & \multirow[t]{2}{*}{$\operatorname{Dip}\left({ }^{\circ}\right)$} & \multirow[t]{2}{*}{ Rake $\left(^{\circ}\right)$} & \multirow[t]{2}{*}{$\mu(\mathrm{Pa})$} & \multirow[t]{2}{*}{$M_{w}$} \\
\hline & & & Lon $(\mathrm{W})$ & Lat $(\mathrm{N})$ & & & & & & & \\
\hline MPF & 129 & 70 & $9^{\circ} 53^{\prime} 24^{\prime \prime}$ & $36^{\circ} 34^{\prime} 26^{\prime \prime}$ & 4.0 & 8.0 & 20.0 & 35 & 90 & $3.0 \times 10^{10}$ & 8.1 \\
\hline $\mathrm{HSF}$ & 165 & 70 & $9^{\circ} 54^{\prime} 47^{\prime \prime}$ & $35^{\circ} 47^{\prime} 45^{\prime \prime}$ & 4.0 & 10.7 & 42.1 & 35 & 90 & $3.0 \times 10^{10}$ & 8.3 \\
\hline
\end{tabular}

MPF Marques de Pombal fault, $H S F$ Horseshoe fault, $L$ the fault length in kilometers, $W$ the fault width in kilometers, $D$ the depth from the sea bottom to the top of the fault in kilometers; $\mu$ the shear modulus and $M_{w}$ the moment magnitude

boundary scheme to track the moving shoreline (LiU et al., 1995) is adopted. To parameterize the effect of the bottom friction in both shallow water and flooded areas, the Manning coefficient, which varies with the bottom roughness, is used in the numerical model.

The impact of tsunamis generated in the Gulf of Cadiz is analyzed along the coastal areas of south Portugal using the computed MWH, maximum flow depth and current velocities.

\section{Results and Discussion}

Tsunami modeling results were processed to obtain the spatial distribution of MWH as well as the inland maximum flow depths and flow velocities for the Lagos-Portimão region. MWHs were computed in the parent grid to show the large-scale tsunami energy direction toward the Gulf of Cadiz coasts. However, inundation and current velocity computations were conducted in the high-resolution grid to evaluate the local tsunami impact.

\subsection{Maximum Wave Height}

The results of MWH computations for MPF and HSF are presented in Figs. 3a and 4a, respectively. Examination of these results shows that both scenarios steer tsunami energy toward the coastal areas of the Algarve region. The MPF generates large waves of 2-7-m amplitude along the southern Portuguese coast. However, the impact of the HSF in this area, compared to the one of MPF, is less with a MWH of $4 \mathrm{~m}$. It is clear that the fault strike constrains the tsunami energy distribution. At first order, the tsunami amplitude is maximal in the direction 
perpendicular to the fault strike, but when the wave reaches the near-shore, the bathymetry affects the wave form and the shallow water amplifies the wave amplitude. For such reasons, the results of the spatial distribution of MWH indicate a concentration of the maximal tsunami energy in the Algarve coastal region for MPF and a radiation of the maximal tsunami energy toward northwest Morocco for the HSF. Also, the shallower depths SW of Cap San Vicent (Fig. 2) act to guide tsunami energy from the northern area of the MPF fault to the Algarve coast (Fig. 3), whereas the orientation and more southerly location of the HSF fault (Fig. 4) does not allow this to happen, or at least to a much less extent.

It must be added that in spite of the scenarios' relatively modest $(\sim 8)$ magnitude (Table 1$)$, the initial sea surface displacements resulting from the proposed earthquake mechanisms reach $7 \mathrm{~m}$. This is primarily due to two main reasons: (1) the shallow rupture mechanism and (2) the spatially varying slip distribution. GeIST and DMOwsKa (1999) show that the distributed slip affects the initial wave profile, giving wave amplitude that is greater than that for a uniform slip distribution, and it therefore affects the tsunami wave field away from the source region. Such effects are particularly important for local tsunamis, as is the case in the Gulf of Cadiz, where the resulting tsunami run-up is significantly affected by the initial wave profile (Geist and DMowsKa, 1999).

\subsection{Mapping Inundation: Effect of Bottom Friction}

Figures $3 \mathrm{~b}$ and $4 \mathrm{~b}$ show the spatial distribution of inundation and flow depths overland in the LagosPortimão area for the two proposed earthquake scenarios considering different bottom friction conditions. These results do not take into account the tide. Both scenarios produce large inundations within the study area. Clearly, the threat posed by the MPF scenario is greater than the one posed by the HSF scenario with respect to the Manning coefficient used. As expected, the changing of the bottom condition affects the maximum flow depth considerably. Figures $3 b .1-3$ and $4 b .1-3$ illustrate the variation of the flow depth with different Manning coefficients $(n=0.000 ; 0.015$ and 0.030$)$. The case with no bottom friction ( $n=0.000$ ) represents the worst case of flooding in terms of flow depth and inundation limits for each tested scenario (Figs. 3b.1, 4b.1). In this case, tsunami flow depths vary from 1 to $7 \mathrm{~m}$ and from 0.5 to $5 \mathrm{~m}$ at the Lagos-Portimão site for MPF

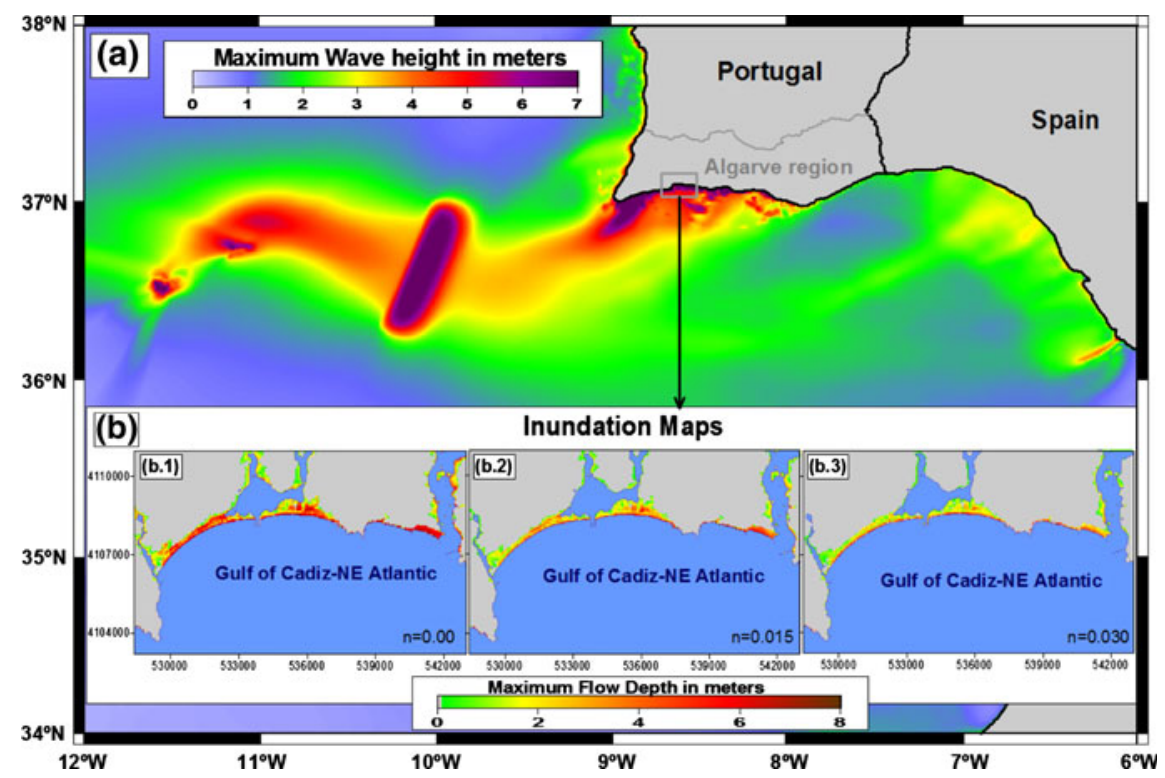

Figure 3

Results of the propagation and run-up modeling for the Marques de Pombal fault 


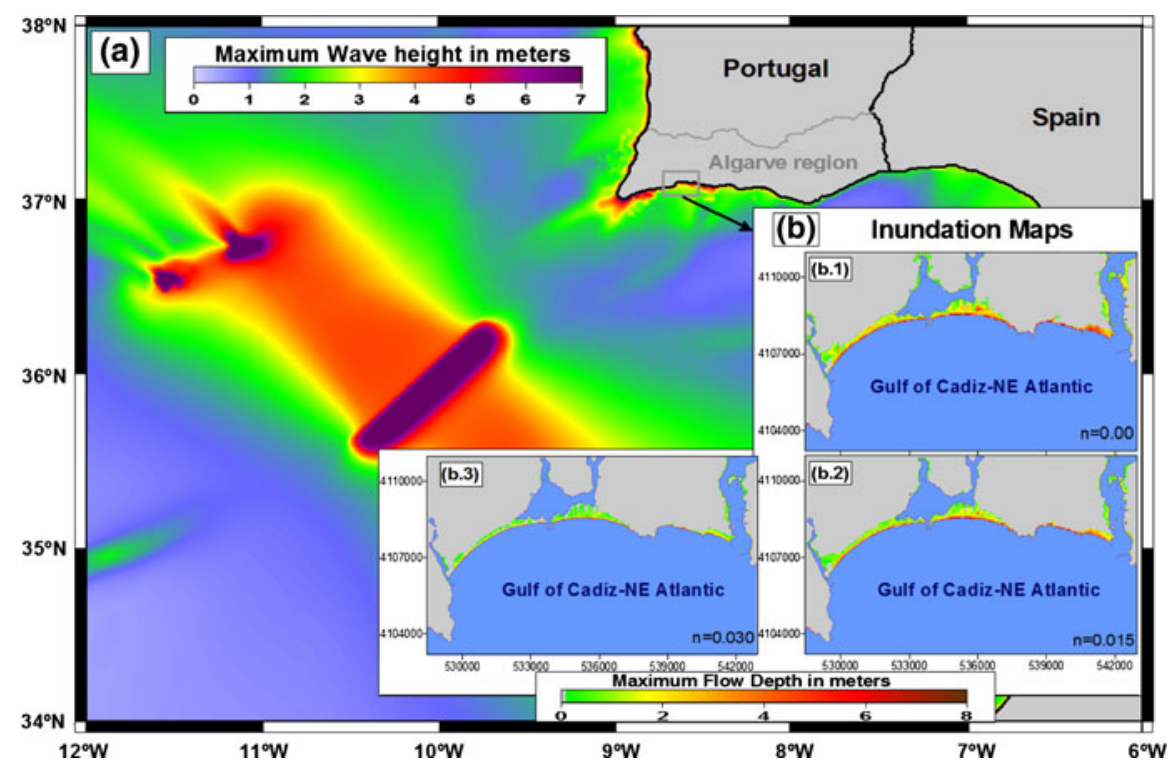

Figure 4

Results of the propagation and run-up modeling for the Horseshoe fault

and HSF, respectively. These values decrease considerably and vary from 0.5 to $4.5 \mathrm{~m}$ and from 0.2 to $3 \mathrm{~m}$ for MPF and HSF, respectively, when a large bottom friction is considered $(n=0.030)$ (Figs. 3b.3, 4b.3).

In Fig. 5, we also present the effect of the variation of the bottom roughness on the computed inundation limits for the MPF scenario at the Lagos-Portimão site. The inundation limits are clearly distinguished. From these results, it can be easily observed that the flooded area decreases when the bottom friction increases. A maximum inland inundation distance of $1.10 \mathrm{~km}$ is reached for no bottom roughness; on the other hand, at the same location, distances of 1.0 and $0.80 \mathrm{~km}$ are computed for the values of 0.015 and 0.030 of Manning's coefficient, respectively.

The flat topography and the presence of streams in the area contribute to increasing the flooded area. Other factors, such as the earthquake source parameters, earthquake location and near-shore bathymetry, also control the variation in flow depth in the LagosPortimão sector. As expected the inundation parameters (run-up and maximum inundation distance) obtained with zero Manning's coefficient are greater than those obtained with Manning's coefficients of 0.015 and 0.030 .
The use of $n=0.000$ for Manning's coefficient may overestimate the inundation parameters in the area for a tsunami scenario corresponding to an 8.1-8.3 earthquake, but it can also be considered as an approximation to the worst case scenario. However, various natural and man-made obstructions exist, which were not included in the DTM model; such obstructions could dissipate the tsunami energy and consequently reduce the run-up (W $\mathrm{W}_{\text {IJETUNGE, }}$ 2009). The inclusion of the effects of vegetation, buildings and other structures in modeling inundation remains difficult.

\subsection{Current Velocity: Effect of Bottom Friction}

The sensitivity of the overland current velocity to the variation of the bottom roughness is investigated, and the results are illustrated in the Fig. 6. These results present the impact of the MPF scenario at the site of Lagos-Portimão in terms of overland current speed. The effect of the bottom roughness on the computed flow speed is considerable. For the case with no bottom friction $(n=0.000)$, the maximum current speed exceeds $8 \mathrm{~m} / \mathrm{s}$ at some locations (Fig. 6a). This value of overland flood velocity decreases and reaches 6 and $3 \mathrm{~m} / \mathrm{s}$ for Manning's 


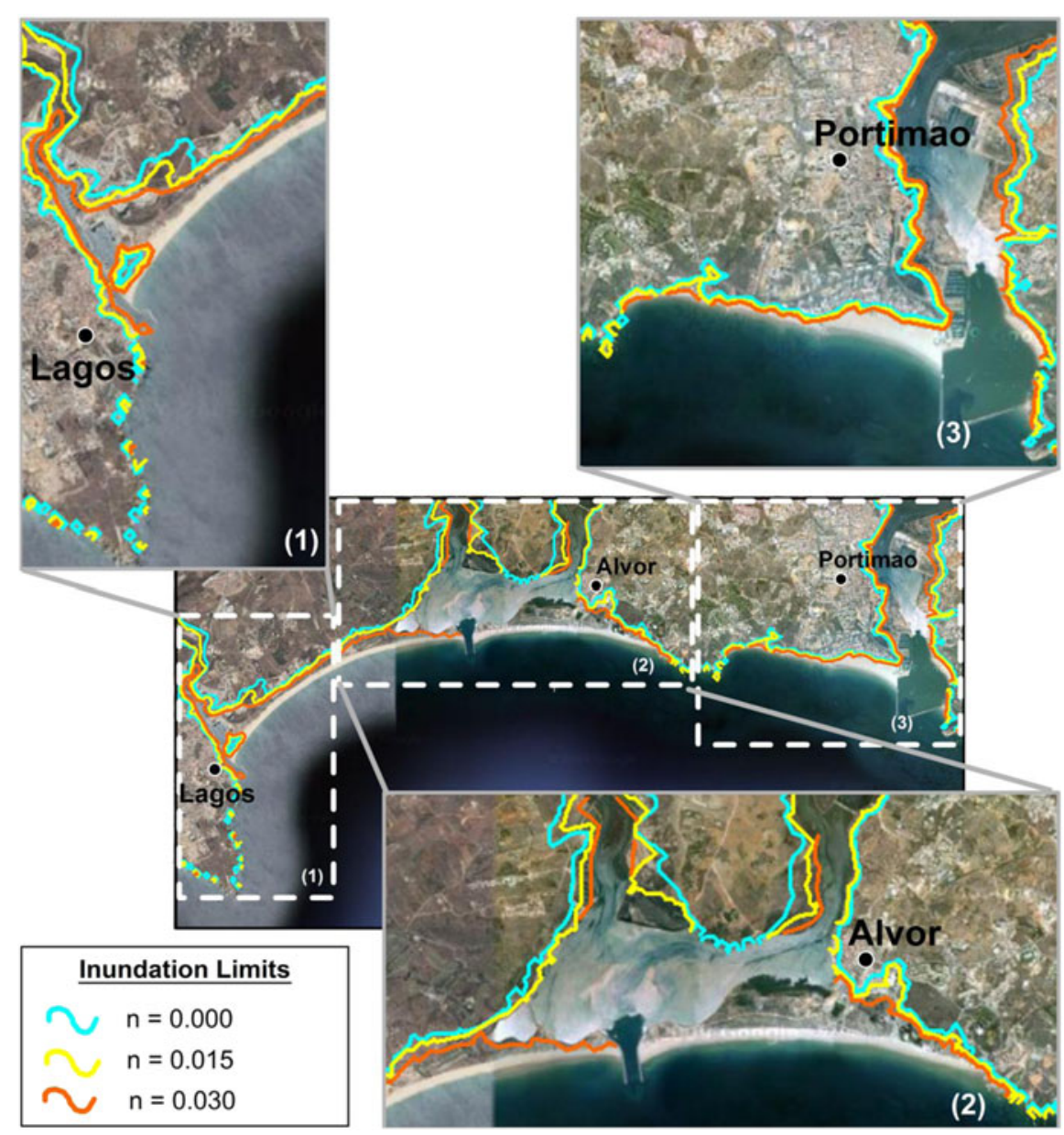

Figure 5

Comparison of inundation areas computed for three different values of the Manning coefficient $(n=0.000,0.015$ and 0.030$)$ for the MPF scenario

coefficients of 0.015 and 0.030 , respectively (Fig. 6b, c). Waves of such velocities could have devastating consequences on coastal communities and buildings.

According to an experimental study by TAKAHASHI (2005), at locations where the flow depth exceeds $0.5 \mathrm{~m}$, generally people cannot remain standing if the current velocity exceeds $1.5 \mathrm{~m} / \mathrm{s}$. Current velocity computation results obtained for different bottom friction conditions (Fig. 6a-c) show values much larger than $1.5 \mathrm{~m} / \mathrm{s}$ at most locations in the studied area, thus indicating that the Lagos-Portimão communities are exposed to a major tsunami threat. We note here that the computed flow speed may be overestimated due to the fact that the numerical simulations were done over bare land with a uniform distribution of the bottom friction, and both natural and man-made obstacles were not included. On the other hand, the presence of buildings within the flooded area could channel the flow and consequently increase the flow velocities locally, as occurred during the Sumatra event of 2004.

\subsection{Comparison with Historical Data}

The comparison of the model results with the reported historical data for the 1755 event must consider the fact that: (1) the tsunami scenarios used in this study correspond to earthquakes of 8.1 and 8.3 magnitudes, which are smaller than the estimated magnitude for the 1755 event, and (2) the land and 


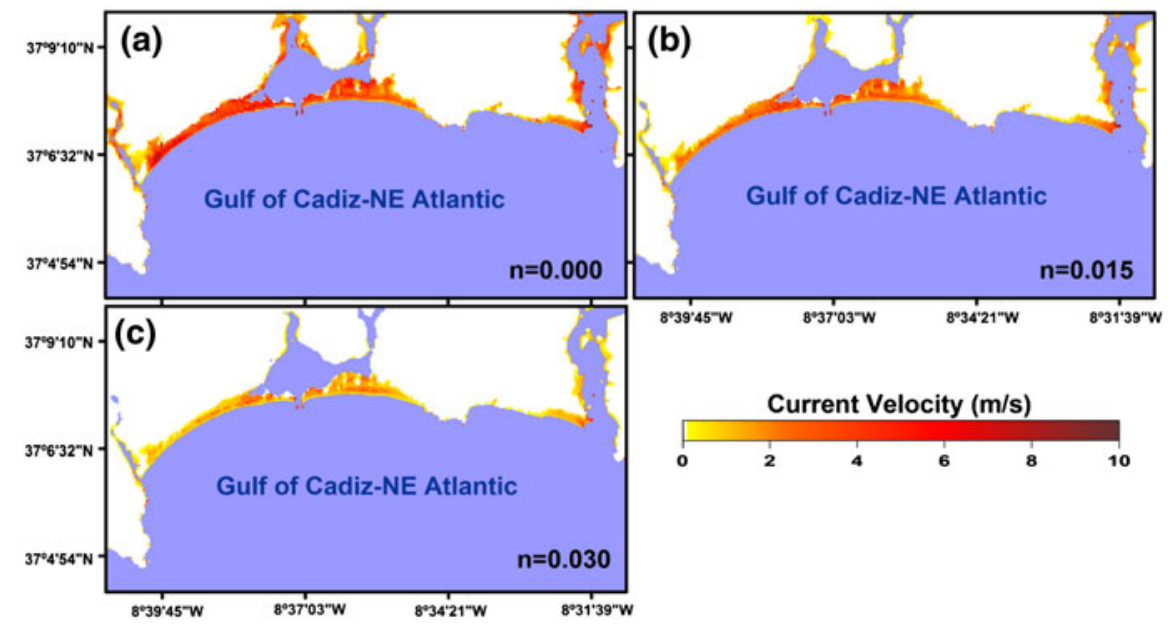

Figure 6

Results of the water current velocity computed for three different values of the Manning coefficient $(n=0.000,0.015$ and 0.030$)$ for the MPF scenario

waters near the shoreline and the harbor have undergone significant changes since the late eighteenth century, including dredging and construction of the harbor, marinas and breakwaters.

Given these two points, we compared the inundation results corresponding to the MPF scenario (for $n=0.00$ ) with the historical reports, only to check the likelihood of our results (see Figs. 7, 8). The analysis of Fig. 7 shows that the highest flow depths and maximum inundation distance (MID) values occurred in the Alvor and Portimão areas.
Examination of Fig. 8a indicates that in the area west of the Lagos town center, the mean inundation distance reaches $500 \mathrm{~m}$, with a local maximum inundation depth of $6 \mathrm{~m}$. MDJF (1756 in BAPTISTA and Miranda, 2009) described the 1755 event at the Lagos site as: “(...) the sea entered onshore 7 poles high; the very strong city walls suffered this misfortune(...);" another report from an eyewitness described "the sea rising up till 13 and a half palms ( $~ 7 \mathrm{~m}$ ) high" (BAptista and Miranda, 2009). These reports correlate well with the computed results, if we consider that the quoted value of $\sim 7 \mathrm{~m}$ corresponds

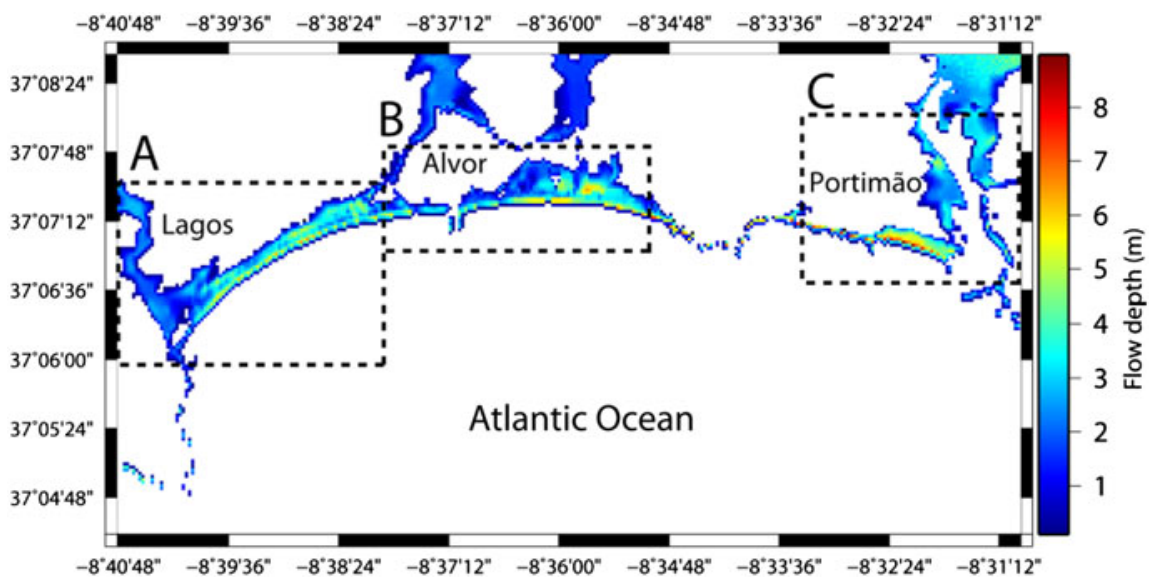

Figure 7

Inundation map for the study area resulting from the MPF earthquake scenario with a $n=0.000$ Manning's coefficient; flow depth scale in meters 

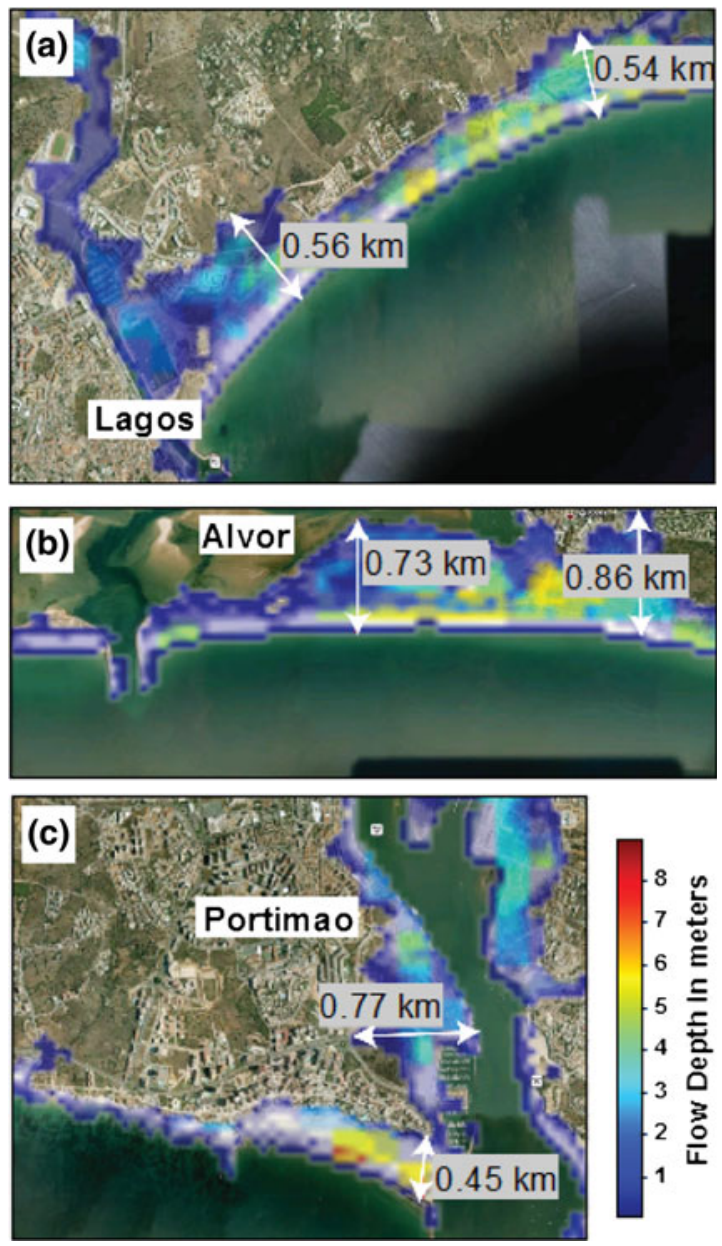

Figure 8

Flooding maps and computed inundation distances for the MPF earthquake scenario with a $n=0.000$ Manning's coefficient. Insets for Lagos (a), Alvor (b) and Portimão (c)

to the maximum flow depth observed for the 1755 event.

Figure $8 \mathrm{~b}$ shows that the computed MID values at Alvor reach 700 and $860 \mathrm{~m}$, and the local maximum flow depth is $7.3 \mathrm{~m}$. These results are in agreement with reported inundation distances for the 1755 event indicating a value of $600 \mathrm{~m}$ (LoPEs, 1841; PEDROSA and Gonçalves, 2008).

For the area of Portimão (Fig. 8c) the maximum flow depth value of $8 \mathrm{~m}$ is computed at a distance of circa $100 \mathrm{~m}$ from the shoreline. In this area the rivers and the streams act as wave channels causing the flooding of the river/stream banks within $3 \mathrm{~km}$ from the shoreline. A similar phenomenon is reported by CAstro (1768) for the 1755 event: "In the town of
Portimão (...) alarming/formidable waves run upstream more than one league."

\section{Conclusion}

We simulated the coastal inundation and the overland current velocity for two tsunamigenic scenarios. Both scenarios produce significant flow depths and current velocities. The areas where the small Algarve rivers reach the ocean, due to their morphological characteristics, with relatively large shallow areas, will sustain most of the inundation and damage.

We investigated the sensitivity of the inundation limit and the flow speed with respect to the bottom friction coefficients used $(n=0.000,0.015$ and 0.030 in this study). As expected, both the flow depth and speed decrease when the bottom friction increases, but in all cases the inundated area is significant. When compared to the historical descriptions of the 1755 event, our numerical model shows values somehow lower than the maxima described in historical documents; this is in agreement with the fact that our target magnitude was 8.1-8.3, while the 1755 event is supposed to have been generated by a 8.5-8.7 earthquake.

As noted previously by Lima et al. (2010) the tide level in the area is relevant, 3-4 m, thus affecting the flooding distances, flow depths and run-up. This fact should be taken into account in tsunami risk studies, although we know that the probability of simultaneous occurrence of a high tide and tsunami worst case scenario is very low. The Lagos-Portimão coastal segment is the location of some of the more popular beaches, which are crowded during the summer, and this study clearly shows that these will be inundated, up to $7 \mathrm{~m}$ in height, with flow velocities in the range of 3-8 m/s. These results together with the very short tsunami travel time to the coast must be taken into account by emergency planners in the design of evacuation routes.

\section{Acknowledgments}

This work was funded by NEAREST and TRANSFER 6FP European Union projects, and by the 
Portuguese authority for civil protection, ANPC. The authors wish to thank the anonymous reviewers for their valuable and constructive comments.

\section{REFERENCES}

Акг, K. (1966), Earthquake mechanism, Tectonophysics 13(1-4), 423-432.

Baptista, M.A., Miranda, P.M.A., Mendes-Victor, L. (1992), Maximum entropy analysis of Portuguese tsunamis: The tsunamis of 28/02/1969 and 26/05/1975, Sci. Tsunami Hazards, 10(1), 9-20.

Baptista, M.A., Heitor, S., Miranda, J.M., Miranda, P., and Mendes-Victor, L. (1998a), The 1755 Lisbon tsunami; evaluation of the tsunami parameters, J. Geodynamics 25, 143-157.

Baptista, M.A., Miranda, P.M.A., Miranda, J.M., and MendesVICTOR, L. (1998b), Constraints on the source of the 1755 Lisbon tsunami inferred from numerical modeling of historical data on the source of the 1755 Lisbon tsunami, J. Geodynamics 25, 159-174.

Baptista, M.A., Miranda, J.M., Chirericci, F., and Zitellini, N. (2003), New Study of the 1755 Earthquake Source Based on Multi-channel Seismic Survey Data and Tsunami Modeling, Nat. Hazards Earth Syst. Sci. 3, 333-340. http://www.nat-hazardsearth-syst-sci.net/3/333/2003/nhess-3-333-2003.html.

Baptista, M.A., Miranda, J.M., Lima, V., Catalão, J., and RoquETE, P. (2008), Technical Report: Estudo do Risco Sísmico e de Tsunamis no Algarve. Contract research to ANPC - Autoridade Nacional de Protecção Civil, Portugal. (in Portuguese).

Baptista, M.A., and Miranda, J.M. (2009), Revision of the Portuguese catalog of tsunamis, Nat. Hazards Earth Syst. Sci. 9, 25-42. http://www.nat-hazards-earth-syst-sci.net/9/25/2009/ nhess-9-25-2009.html

Bondevik, S., Mangerud, J., Dawson, S., Dawson, A.G., and LoHNe, O. (2003), Record-breaking height for 8000 years-old tsunami in the North Atlantic. EOS, 84: 289-300.

Bondevik, S., Løvholt, F., Harbitz, C., Mangerud, J., Dawson, A., and Svendsen, J.I. (2005), The Storegga slide tsunami - Comparing field observations with numerical simulations. Marine and Petroleum Geology 22,195-208.

Buforn, E., Udias, A., and Colombas, M. (1988), Seismicity, source mechanisms and tectonics of the Azores - Gibraltar plateboundary, Tectonophysics 152, 89-118.

Castro, D.L.F. (1768). História Geral de Portugal e suas conquistas (offerecida à Sacra Real e Augusta Magestade da Fidelíssima Raynha D. Maria I, Nossa Senhor), Livro 1, Cap. IV, 21-36. Manuscript 691 of the database of Fundo Antigo da Academia de Ciências de Lisboa. (in Portuguese).

FUKAO, Y. (1973), Thrust faulting at a lithosphere plate boundary. The Portugal earthquake of 1969, Earth Planet Sci. Lett. 18, 205-216.

GeIst, E.L., and DмоwsкA, R. (1999), Local tsunamis and distributed slip at the source, Pure Appl. Geophys. 154, 485-512.

Gjevik, B., Pedersen, G., Dybesland, E., Harbitz, C.B., Miranda, P.M.A., Baptista, M.A., Mendes-Victor, L., Heinrich, Ph., Roche, R., and Guesima, M. (1997), Modeling tsunamis from earthquake sources near Gorringe Bank southwest of Portugal, J. Geophys. Res. 102(C13), 27931-27949.
Heinrich, Ph., Baptista, M.A., Miranda, P.M.A. (1994). Numerical Simulation of the 1969 Tsunami along the Portuguese Coasts. Preliminary Results, Sci. Tsunami Hazards 12(1), 3-23.

Kaabouben, F., Brahim, A.I., Toto, E.A., Baptista, M.A., MiranDA, J.M., SoAres, P., and Luis, J.F. (2008), On the focal mechanism of the 26.05.1975 North Atlantic event contribution from tsunami modeling, J. Seismology, doi:10.1007/s10950008-9110-6.

KANAMORI, H., and ANDERSON, D.L. (1977), Importance of physical dispersion in surface-wave and free oscillation problemsreview, Rev. Geophys. 15(1), 105-112.

Lima, V.V., Miranda, J.M., Baptista, M.A., Catalão, J.C., Gonzalez, M., Otero, L., Olabarrieta, M., Álvarez-Gómez, J.A., and CARREÑo, E. (2010), Impact of a 1755 like tsunami in Huelva Spain, Nat. Hazards Earth Syst. Sci. 10, 139-148. http://www.nat-hazards-earth-syst-sci.net/10/139/2010/nhess-10139-2010.html.

Liu, P.L.-F., Cho, Y-S., Briggs, M. J., Synolakis, C.E., and KANOGLU, U. (1995), Run-up of solitary waves on a circular island, J. Fluid Mech. 302, 259-285.

Liu, P. L-F., Woo, S-B., and Chо, Y-S. (1998), Computer programs for tsunami propagation and inundation, Technical report, Cornell University.

LoPEs, J.B.S. (1841), Corografia ou memória económica do reino do Algarve, Ed. Academia de Ciências Lisboa, 169 pp. (in Portuguese).

LuIs, J.F. (2007), Mirone: A multi-purpose tool for exploring grid data, Computers and Geosciences 33, 31-41.

Luque, L., Lario, J., Zazo, C., Goy, J.L., Dabrio, C.J., and Silva, P.G. (2001), Tsunami deposits as paleoseismic inidcators: examples from the Spanish coast, Acta Geologica Hispanica 36(3-4), 197-211.

Luque, L., Lario, J., Civic, J., Silva, P.G., Zazo, C., Goy, J.L., and DABRio, C.J. (2002), Sedimentary record of a tsunami during Roman times, Bay of Cadiz, Spain, Journal of Quaternary Science 17(5-6), 623-631.

Mansinha, L., and SMYlie, D.E. (1971), The displacement field of inclined faults, Bull. Seismol. Soc. Am. 61(5), 1433-1440.

Miranda, J.M., Baptista, M.A., Terrinha, P., and Matias, L. (2008), Tsunamigenic source areas for Portugal mainland, Iberia, Oral Communication, Session on Tsunami Early Warning Systems and Tsunami Risk Mitigation in the European-Mediterranean Region, 31st General Assembly of the European Seismological Commission, Crete, Greece.

Omira, R., Baptista, M.A., Matias, L., Miranda, J.M., Catita, C., CArrilho, F., and Toto, E. (2009a), Design of a Sea-level Tsunami Detection Network for the Gulf of Cadiz, Nat. Hazards Earth Syst. Sci. 9, 1327-1338. http://www.nat-hazards-earthsyst-sci.net/9/1327/2009/nhess-9-1327-2009.html.

Omira, R., Baptista, M.A., Miranda, J.M., Toto, E., Catita, C., and CAtalÃo, J. (2009b), Tsunami vulnerability assessment of Casablanca-Morocco using numerical modelling and GIS tools, Natural Hazards, doi:10.1007/s11069-009-9454-4.

Pedrosa, F.T., and Gonçalves, J. (2008), The 1755 earthquake in the Algarve (South of Portugal): what would happen nowadays? Adv. Geosci. 14, 59-63.

Scholz, C.H. (1982), Scaling laws for large earthquakes: consequences for physical models, Bull. Seismol. Soc. Am. 72, 1-14.

TAKahashi, S. (2005), Tsunami disasters and their prevention in Japan-Toward the performance design of coastal defences, 
Proceedings of the International Symposium on Disaster Reduction on Coasts, Melbourne, Australia, 2005.

Tinti, S., and Armigliato, A. (2003), The use of scenarios to evaluate the tsunami impact in southern Italy, Marine Geology 199, 221-243.

WANG, X., and LiU, P.L-F. (2007), COMCOT user manual-version 1.6. School of Civil and Environmental Engineering, Cornell
University Ithaca, NY 14853, USA. http://ceeserver.cee.cornell. edu/pll-group/doc/comcot_user_manual_v1_6.pdf WiJETUNGe, J.J. (2009), Numerical simulation and field survey of inundation due to 2004 Indian Ocean tsunami in Trincomalee, Sri Lanka, Natural Hazards, doi:10.1007/s11069-009-9459-z.

(Received January 5, 2010, revised April 22, 2010, accepted April 28, 2010, Published online November 13, 2010) 